\title{
Lactic acid bacteria diversity in corn silage produced in Minas Gerais (Brazil)
}

\author{
Andréia de Oliveira dos Santos ${ }^{1,2} \cdot$ Carla Luiza da Silva Ávila $^{3}(1)$ - Célia Soares ${ }^{2} \cdot$ Beatriz Ferreira Carvalho $^{3}$. \\ Rosane Freitas Schwan ${ }^{1} \cdot$ Nelson Lima ${ }^{2}$
}

Received: 23 May 2019 / Accepted: 3 November 2019/Published online: 18 November 2019

(C) The Author(s) 2019

\begin{abstract}
Purpose The diversity of lactic acid bacteria (LAB) in silages produced in warm climate countries is not well known. This study aimed to identify and characterise the metabolic and genotypic aspects of autochthonous LAB isolated from corn silage produced in the state of Minas Gerais, Brazil.

Methods Eighty-eight LAB were isolated. To evaluate their performance at the strain level, all isolates were distinguished among strains using random amplified polymorphic DNA polymerase chain reaction (RAPD-PCR) and repetitive extragenic palindromic PCR (REP-PCR) techniques. The organic acid and ethanol production were determined by high-performance liquid chromatography (HPLC).

Result The fingerprints obtained by RAPD-PCR with a M13 primer were more discriminatory than those obtained with the REPPCR technique using a $(\mathrm{GACA})_{4}$ primer. Moreover, 28 representative isolates were identified as Lactobacillus acidophilus, L. buchneri, L. casei, L. diolivorans, L. hilgardii, L. paracasei, L. parafarraginis, L. plantarum, L. rhamnosus, L. zeae and Pediococcus acidilactici. Different fingerprinting profiles between isolates within the same species were observed. However, some strains isolated from different silages showed the same band profile, thus suggesting the presence of clusters with high similar fingerprints in silages from various regions.

Conclusion A variation in LAB diversity was observed in the silages of the evaluated regions, with L. rhamnosus and L. buchneri showing the highest distribution. Differences in organic acid production were observed among the strains belonging to the same species. This research contributes to a better understanding of the LAB community present in corn silage produced in warm climates. These strains will be studied as potential silage starters.
\end{abstract}

Keywords Molecular characterisation $\cdot$ Corn silage $\cdot$ RAPD-PCR $\cdot$ Lactic acid bacteria

\section{Introduction}

Corn (Zea mays L.) has adequate characteristics for silage fermentation and is the forage often used in many parts of the world (Bernardes and do Rêgo 2014; Khan et al. 2015).

Carla Luiza da Silva Ávila

carlaavila@dzo.ufla.br

1 Departamento de Biologia, Universidade Federal de Lavras, Lavras, Minas Gerais 37200-000, Brazil

2 Centro de Engenharia Biológica, Universidade do Minho, 4710-057 Braga, Portugal

3 Departamento de Zootecnia, Universidade Federal de Lavras, Lavras, Minas Gerais 37200-000, Brazil
Due to the nutritional quality, this forage has been extensively used to optimise the yield of milk production in order to meet the increasing demand for dairy products (Yang et al. 2019). The use of corn silages has increased in several countries such as Brazil, Mexico (South and Central America) (Bernardes and do Rêgo 2014; Prospero-Bernal et al. 2017), Thailand, Malaysia (Asia) (Ohmomo et al. 2002; Khaing et al. 2015) and Kenya and Ethiopia (Africa) (Tamir et al. 2012; Makau et al. 2018).

Typically, many aerobic and anaerobic microorganisms are found in silage and affect its quality. As the anaerobic atmosphere inside the silo increases, the population of various facultative anaerobic microorganisms also rises, primarily fermenting sugars into organic acids (lactic, acetic, propionic, butyric, formic, caproic and valeric acids), which in turn exhibit antimicrobial activity preventing the spoilage by 
undesirable microorganisms such as yeasts and filamentous fungi (Borreani et al. 2018; O'Brian et al. 2007). Moreover, the impact of the presence of filamentous fungi can increase if toxic secondary metabolites (mycotoxins) are produced. At the time of ensiling, plant material encloses a large range of microorganisms (Fabiszewska et al. 2019), but the fermentation process favours the multiplication of lactic acid bacteria (LAB). LAB are part of the main group of microorganisms that act in the silage fermentation process. LAB include bacteria from a number of genera, such as Enterococcus, Lactobacillus, Lactococcus, Leuconostoc, Pediococcus, Weissela and Streptococcus (Vandamme et al. 2014). Of these, Pediococcus, Lactococcus, Enterococcus and Weissela are important in the initial stage of fermentation because they ensure the environment remains acidic, which becomes predominantly colonised by the Lactobacillus genus (Lin et al. 1992).

Environmental factors such as temperature, humidity and precipitation seem to have influence in the microbial population in silages, especially in warm and humid areas (Muck, 2013). During the ensiling process, rainfall and humidity have impact in the epiphytic bacterial community, and temperature affects the richness of bacterial species and subsequent silage fermentation. Fortunately, these factors seem to have negative impact in some undesirable microorganisms and do not affect the Lactobacillus and Leuconostoc genus (Guan et al. 2018).

It is generally recognised that changes in the LAB population diversity occurred during the ensiling process in which an adequate ensilage usually starts with homofermentative LAB species quickly growing after sealing, later being replaced by heterofermentative LAB species when substrate availability becomes limited (McDonald et al. 1966; McDonald et al. 1991; Yang et al. 2006). Furthermore, higher ensiling temperatures also contribute to accelerate the shift from a homolactic to a heterolactic microbial population (Bernardes et al. 2018).

The identification of autochthonous strains and the study of $\mathrm{LAB}$ in silage produced under different conditions are necessary to improve silage quality. LAB identification is an important step, but its fermentation performance is always strain dependent. Therefore, it is of primary importance to use techniques capable of discriminating among strains. Typing methods might be used to trace individual strains (Abdollahniya et al. 2018). Several studies have reported success using random amplified polymorphic DNA polymerase chain reaction (RAPD-PCR) for the differentiation of LAB isolates (Rossetti and Giraffa 2005; Parente et al. 2016; Abdollahniya et al. 2018). Repetitive extragenic palindromic PCR (REP-PCR) is another powerful tool used to identify several types of LAB, including Lactobacilli (Gevers et al. 2001; Dolci and Cocolin 2017). These techniques can be used to rapidly compare a large number of isolates and reveal relationships at the species and subspecies levels. Despite the importance of culture-independent techniques, classic studies that use the recovery of microorganisms in culture media remain necessary.

To the best of our knowledge, there is no report in the literature showing the isolation and identification of LAB present in farm scale corn silage produced in warm climates. Thus, the present study aimed to identify the LAB isolated from corn silage produced in farms from different regions of the state of Minas Gerais, Brazil, using a genotypic and phenotypic (organic acid and ethanol production) approach.

\section{Materials and methods}

\section{Sampling and bacterial isolation}

LAB strains used in this study were isolated from samples of corn silages produced in bunker silos in 9 Brazilian microregions of Minas Gerais State: Lavras $\left(21^{\circ} 14^{\prime} \mathrm{S}, 44^{\circ} 59^{\prime} \mathrm{W}\right.$, 919 m), Elói Mendes ( $\left.21^{\circ} 36^{\prime} \mathrm{S}, 45^{\circ} 33^{\prime} \mathrm{W}, 907 \mathrm{~m}\right)$, Silvianópolis $\left(22^{\circ} 01^{\prime} \mathrm{S}, 45^{\circ} 50^{\prime} \mathrm{W}, 897 \mathrm{~m}\right)$, São Sebastião do Paraíso $\left(20^{\circ} 55^{\prime} \mathrm{S}, 46^{\circ} 59^{\prime} \mathrm{W}, 991 \mathrm{~m}\right)$, Passos $\left(20^{\circ} 43^{\prime} \mathrm{S}\right.$, $46^{\circ} 36^{\prime} \mathrm{W}, 745 \mathrm{~m}$ ), Muzambinho ( $21^{\circ} 22^{\prime} \mathrm{S}, 46^{\circ} 31^{\prime} \mathrm{W}, 1048$ $\mathrm{m})$, Piranguinho $\left(22^{\circ} 24^{\prime} \mathrm{S}, 45^{\circ} 31^{\prime} \mathrm{W}, 837 \mathrm{~m}\right)$, Itumirim $\left(21^{\circ}\right.$ $\left.19^{\prime} \mathrm{S}, 44^{\circ} 52^{\prime} \mathrm{W}, 871 \mathrm{~m}\right)$ and Nepomuceno $\left(21^{\circ} 14^{\prime} \mathrm{S}, 45^{\circ} 14^{\prime}\right.$ $\mathrm{W}, 840 \mathrm{~m}$ ) (Santos 2016). The climate in these regions is classified as Cwa (warm temperate climate with dry winter), the precipitation occurs mainly from October to March and the average temperatures in the winter and summer are $19.7^{\circ} \mathrm{C}$ and $22.7^{\circ} \mathrm{C}$, respectively (Sá Júnior et al. 2012). Corn silage samples were collected from 54 dairy farms, six from each region. For the bacterial isolation experiment, silage samples were selected according to fermentative characteristics of $\mathrm{pH}$ and temperature. The total count of yeast, filamentous fungi and bacteria (Enterobacteriaceae and aerobic spore-forming bacteria) were also taken into consideration (Santos 2016; Santos et al. 2020). In this sense, two samples from each region, one of the farms that showed overall the best (the lowest pH, silage temperature, Enterobacteriaceae, aerobic spore-forming bacteria and yeast and filamentous fungi population) and one of the farm that showed the worst characteristics (opposite to the previously mentioned) were selected, making a total of 18 samples.

A total of 122 bacterial strains were isolated and cultivated at $37^{\circ} \mathrm{C}$ for $48 \mathrm{~h}$ in MRS agar medium (CM0361, Oxoid; Hampshire, England). The isolates were preserved and maintained in frozen stocks at $-80{ }^{\circ} \mathrm{C}$ in MRS broth medium (CM0359, Oxoid) with glycerol $20 \%(v / v)$ as cryoprotective agent.

\section{Genomic DNA extraction}

Isolates were reactivated and $10 \mu \mathrm{L}$ of active broth culture was re-inoculated into $2 \mathrm{~mL}$ MRS broth plus cysteine $(0.5 \mathrm{~g} / \mathrm{L})$ for 
$24 \mathrm{~h}$ at $37^{\circ} \mathrm{C}$. Post incubation, the bacteria cells were harvested by centrifugation at $10,000 \mathrm{rpm}$ for $10 \mathrm{~min}$ at $4{ }^{\circ} \mathrm{C}$. The pellet was used for genomic DNA extraction that was performed according with a protocol previously described by Sachinandan et al. (2010) using phenol-chloroform.

\section{PCR fingerprinting amplification}

Genomic DNA obtained from 105 different strains was used as a template for PCR fingerprinting using the M13 primer with sequence 5'-GAGGGTGGCGGTTCT-3' and (GACA) primer with sequence 5'-GACAGACAGACAGACA-3'. PCR reactions were performed in $25 \mu \mathrm{L}$ reaction mixtures containing NZYTaq 2x Green master Mix (Nzytech; Lisbon, Portugal), genomic DNA (50 ng) and $0.4 \mathrm{mM}$ of primer. Amplification conditions for primer M13 was according Torriani et al. (1999). For primer (GACA) $)_{4}$, amplification reactions were performed according to the optimised protocol previously described by Shehata et al. (2008).

Amplified products were resolved by electrophoresis $(50 \mathrm{~V}$ for $1.5 \mathrm{~h}$ ) on $0.8 \%(w / \mathrm{vol})$ agarose in $0.5 \mathrm{X}$ TAE buffer gels, stained with GreenSafe Premium (MB13201, Nzytech; Lisbon, Portugal) and photographed with a Molecular Imager® ChemiDoc ${ }^{\mathrm{TM}}$ XRS+ Imaging System (170-8070; BioRad Laboratories, CA, USA). One kbp NZYDNA ladder III (MB04402, Nzytech; Lisbon, Portugal) was used as a DNA molecular weight marker and as a normalisation reference.

\section{Identification to species level by $16 \mathrm{~S}$ rRNA gene sequencing}

A total of 28 representatives isolates were selected from the RAPD-PCR clustering and analysed for $16 \mathrm{~S}$ rRNA gene using the primers $27 \mathrm{~F}$ (5'-AGAGTTTGATCCTGG CTCAG-3') and 1492R (5'-GGTTACCTTGTTACGACTT$3^{\prime}$ ) (Lane, 1991). Amplification reactions were performed in a total volume of $50 \mu \mathrm{L}$.

Amplified PCR products were sent to sequencing at STABVIDA (Caparica, Portugal). The sequences were then compared with the Gen-Bank database using the BLAST algorithm (National Center for Biotechnology Information, Maryland, USA).

\section{Characterisation of organic acid and ethanol production}

To determine the organic acid and ethanol produced in the fermentation, the 88 strains were cultivated in MRS broth for $48 \mathrm{~h}$ at $37{ }^{\circ} \mathrm{C}$. After this period, the inoculum was standardised using a spectrophotometer at $620 \mathrm{~nm}$ wavelength at an optical density of 1.0. Subsequently, $200 \mu \mathrm{L}$ of each strain was inoculated into $1.8 \mathrm{~mL}$ of MRS broth, which was incubated at $37^{\circ} \mathrm{C}$. After 48-h fermentation, samples of the cultures were analysed for lactic acid, acetic acid, propionic acid and ethanol, using high-performance liquid chromatography (HPLC) (JASCO model LC 4000; (JASCO International Co., Tokyo, Japan). The acids and ethanol were identified by comparing their retention times with those of known standards. The HPLC apparatus was equipped with a dual-detection system consisting of a UV detector (JASCO UV-2075Plus) and a refractive index detector (JASCO RI2031). An ion exclusion column from BioRad (Aminex HPX-87H; $7.8 \mathrm{~mm}$ i.d., $30 \mathrm{~cm}$ long) operated at $60{ }^{\circ} \mathrm{C}$ was used for the chromatography separation. The mobile phase consisted of $0.005 \mathrm{M}$ sulphuric acid solution with a flow rate of $0.7 \mathrm{~mL} / \mathrm{min}$. The acids were detected by UV absorbance. Ethanol was identified using the refractive index detector.

\section{Data analysis}

Pictures of the obtained gels were analysed using BioNumerics software (version 6.6; Applied Maths BVBA, Sint-Martens-Latem, Belgium). Calculation of similarity of the PCR fingerprinting profiles were based on the Pearson correlation coefficient. A dendrogram was deduced from the matrix of similarities by the unweighted pair group method using arithmetic average (UPGMA) clustering algorithm. Data regarding the production of metabolites by strains were analysed using principal component analysis (PCA) using the XL Stat software, version 7.5. The CORR procedure of SAS 9.3 (SAS Institute 2012) was used to analyses the correlation between the data of silage characteristics as dry matter (DM), $\mathrm{pH}$, lactic, acetic, propionic and butyric acids, ethanol, 1,2propanediol and storage time (Santos et al. 2020) and LAB species identified in the silages.

\section{Results}

\section{Genotypic characterisation}

From the total of isolates, 88 were identified as LAB and 17 isolates as non-LAB. Eleven different species of LAB were identified (Table 1). These species belong to four separate phylogenetic groups of the genus Lactobacillus (L. delbrueckii, L. buchneri, L. casei and L. plantarum) and the genus Pediococcus. Lactobacillus buchneri, and L. rhamnosus were found to have a broad distribution among the silage samples; they were isolated in four different regions. In contrast, L. parafarraginis, L. zeae, L. acidophilus and $L$. casei were isolated in only one region. Samples of corn silage collected in the Itumirim and Nepomuceno regions showed the highest diversity of LAB, and the largest number of identified LAB (23 strains) were isolated from samples collected in the first region; $P$. acidilactici, L. paracasei, 


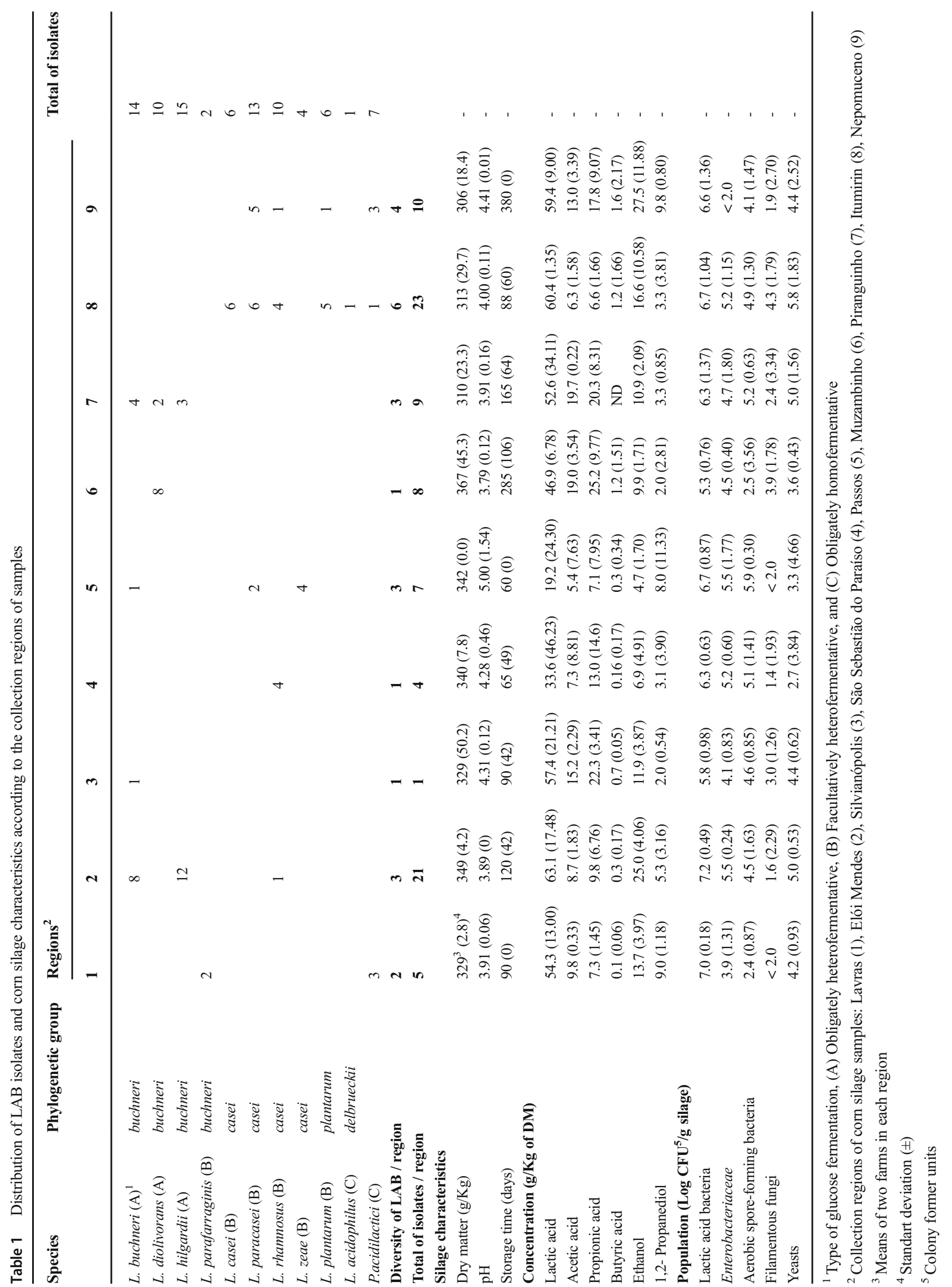


L. rhamnosus and L. plantarum were isolated in both regions. Samples collected in the Silvianópolis, São Sebastião do Paraíso and Muzambinho regions showed the least diversity of LAB; only L. buchneri, L. rhamnosus and L. diolivorans, respectively, were isolated.

The 88 isolates subjected to DNA fingerprinting generated bands ranging in size from 200 to $3000 \mathrm{bp}$. The fingerprints obtained by RAPD-PCR with a M13 primer (Fig. 1) were more complex and discriminatory than those obtained with the REP-PCR technique using a (GACA) $)_{4}$ primer (Fig. 2), being possible to group the fingerprint profiles into welldefined clusters using the first approach, while with REPPCR technique, it was not possible to obtain a quality grouping. The average reproducibility of the M13 primer technique was $96 \%$. This value was used to estimate the differentiation among the isolates (Fig. 1). All the isolates were clearly grouped into separate clusters according to their respective taxonomic designations, with eleven clusters detected (Fig. 1). Based on the grouping by M13, 28 representative isolates were selected and sequenced. The isolates of clusters 1, 3, 4, 5, 6, 7, 8, 10 and 11 were identified as Pediococcus acidilactici (7 isolates), Lactobacillus paracasei (11 isolates), L. rhamnosus (10 isolates), L. diolivorans (10 isolates), L. parafarraginis (2 isolates), L. hilgardii (17 isolates), L. plantarum (6 isolates), L. casei (5 isolates) and L. zeae (4 isolates), respectively. In the cluster 2, L. paracasei ( 2 isolates) and L. acidophilus (1 isolate) were grouped with $95.4 \%$ similarity. Cluster 9 contained 12 isolates of L. buchneri and 1 isolate of $L$. casei, was grouped with $94.6 \%$ similarity.

Isolates of $P$. acidilactici and L. rhamnosus were grouped with $94.2 \%$ and $96.1 \%$ similarity, respectively. The L. diolivorans, L. hilgardii and L. parafarraginis isolates were grouped with $95.7 \%$ similarity. The isolates of L. plantarum and $L$. zeae were grouped with $96.8 \%$ and $98.4 \%$ similarity, respectively.

The presence of $L$. diolivorans was associated with silages with high concentrations of DM $(r=0.562)$, acetic $(r=0.487)$ and propionic $(r=0.526)$ acid and long storage time $(r=$ 0.469) (Table 2). Positive correlation was observed between the presence of L. buchneri and L. hilgardii $(r=0.475)$ in silages. Lactobacillus zeae was more frequently isolated in silages with high $\mathrm{pH}(r=0.891)$ and 1,2-propanediol $(r=$ $0.617)$ concentration and in silages with low acetic $(r=-$ $0.538)$ and propionic $(r=-0.474)$ acid concentrations. The presence of $L$. case $i$ was strongly correlated with $L$. plantarum $(r=0.866)$ and L. acidophilus $(r=0.889)$ species.

\section{Organic acid and ethanol production}

Differences in the production of acids and ethanol were observed between the analysed isolates (Table 3). Isolates classified within the same carbohydrate fermentation patterns and of the same species showed different fermentative characteristics. The CCMA 0770 (L. hilgardii) strain showed the highest production of lactic acid $(25.33 \mathrm{~g} / \mathrm{L})$ and produced $2.55 \mathrm{~g} / \mathrm{L}$ of acetic acid. The strain UFLA SLM 075 (L. diolivorans) showed the highest production of acetic acid $(4.11 \mathrm{~g} / \mathrm{L})$, produced $16.8 \mathrm{~g} / \mathrm{L}$ lactic acid and showed the lowest lactic acid/acetic acid ratio. The highest ratio of lactic acid/acetic acid was 21.8 (L. paracasei). Fifty strains produced less than $0.6 \mathrm{~g} / \mathrm{L}$ ethanol and the other 38 strains produced between 1.17 and $4.64 \mathrm{~g} / \mathrm{L}$, these being predominantly obligately heterofermentatives. The UFLA SLM 223 (P. acidilactici) did not produce any detectable amounts of ethanol or acetic acid, while the UFLA SLM 17 (L. hilgardii) and CCMA 0785 (L. casei) isolates did not produce detectable ethanol. None of the analysed isolates produced detectable amounts of propionic acid.

In the principal component analysis (PCA), the first two components (PC1 and PC2) explain $93.27 \%$ of the total variance (Fig. 3). Some of the isolates only correlated with lactic acid (left upper quadrant). The isolates that correlated with acetic acid (right upper quadrant) also correlated with ethanol. The isolates shown in the lower quadrants produced smaller amounts of both acids and did not correlate with any of the metabolites.

The differences in organic acid production among the 88 isolates were due to the metabolism of the bacteria. In the isolates with a homofermentative metabolism, the average lactic acid content was $18.89 \mathrm{~g} / \mathrm{L}$, which is higher than the average content observed in isolates with an obligately heterofermentative metabolism (14.96 g/L) (Table 3). The average acetic acid content $(2.41 \mathrm{~g} / \mathrm{L})$ and ethanol content $(2.98$ $\mathrm{g} / \mathrm{L}$ ) was relatively higher in the isolates that have an obligately heterofermentative metabolism in comparison with those with a facultatively heterofermentative metabolism $(1.44 \mathrm{~g} / \mathrm{L}$ and $2.41 \mathrm{~g} / \mathrm{L})$ and a homofermentative metabolism $(1.21 \mathrm{~g} / \mathrm{L}$ and $0.27 \mathrm{~g} / \mathrm{L})$, respectively.

\section{Discussion}

All the LAB species found in the evaluated silages were previously associated with silages from corn or other plants produced at different locations, including warm and tropical regions (Parvin and Nishino 2009; Doi et al. 2013; Zhou et al. 2016). Of the 11 isolated species two presented homofermentative metabolism, three obligately heterofermentative metabolism and six species with facultatively heterofermentative metabolism. Heterofermentative bacteria generally resist longer during silage and dominate fermentation over longer storage periods (Carvalho et al. 2016; Blajman et al. 2018). In this study only Lactobacillus diolivorans (obligately heterofermentative) was correlated with long storage time, all silages presented average fermentation times over 65 days. Zhou et al. (2016) examined the 


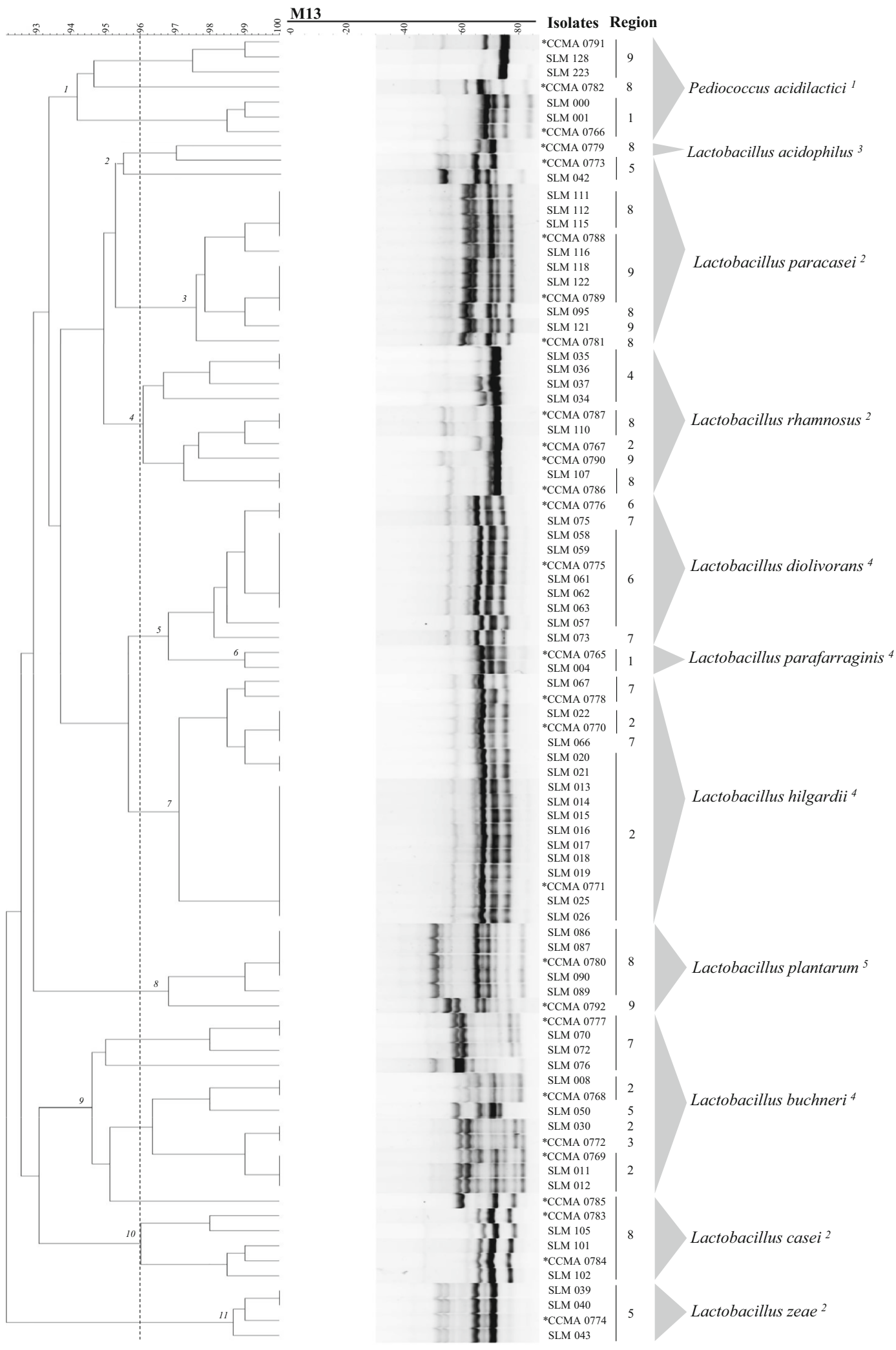

Fig. 1 Dendrogram generated after cluster analysis of fingerprints using M13 primer of the UFLA SLM and CCMA LAB isolates. Stars indicate isolates selected to sequence analysis. Collection regions of corn silage samples: Lavras (1), Elói Mendes (2), Silvianópolis, (3), São Sebastião do

Paraíso (4), Passos (5), Muzambinho (6), Piranguinho (7), Itumirim (8) and Nepomuceno (9). Superscripts codes after species names correspond to the phylogenetic groups: ${ }^{1}$ Pediococcus group; ${ }^{2}$ Lactobacillus casei group; ${ }^{3}$ L. delbruecki group; ${ }^{4}$ L. buchneri group; ${ }^{5}$ L. plantarum group 


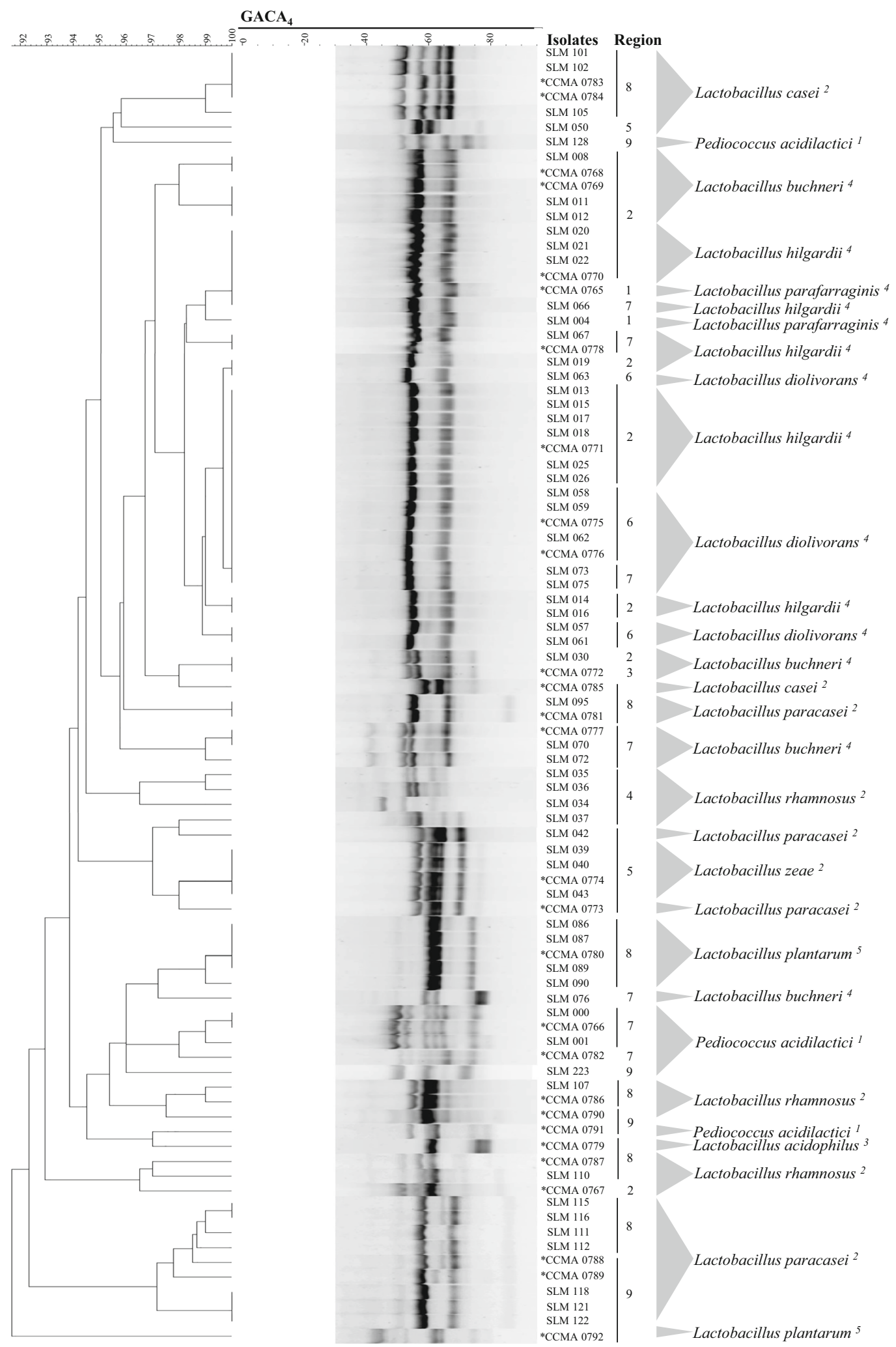

Fig. 2 Dendrogram generated after cluster analysis of REP-PCR fingerprints using $(\mathrm{GACA})_{4}$ primer of the UFLA SLM and CCMA $\mathrm{LAB}$ isolates. Stars indicate isolates selected to sequence analysis. Collection regions of maize silage samples: Lavras (1), Elói Mendes (2), Silvianópolis, (3), São Sebastião do Paraíso (4), Passos (5),
Muzambinho (6), Piranguinho (7), Itumirim (8) and Nepomuceno (9). Superscripts codes after species names correspond to the phylogenetic groups: ${ }^{1}$ Pediococcus group; ${ }^{2}$ Lactobacillus casei group; ${ }^{3}$ L. delbruecki group; ${ }^{4}$ L. buchneri group; ${ }^{5}$ L. plantarum group 


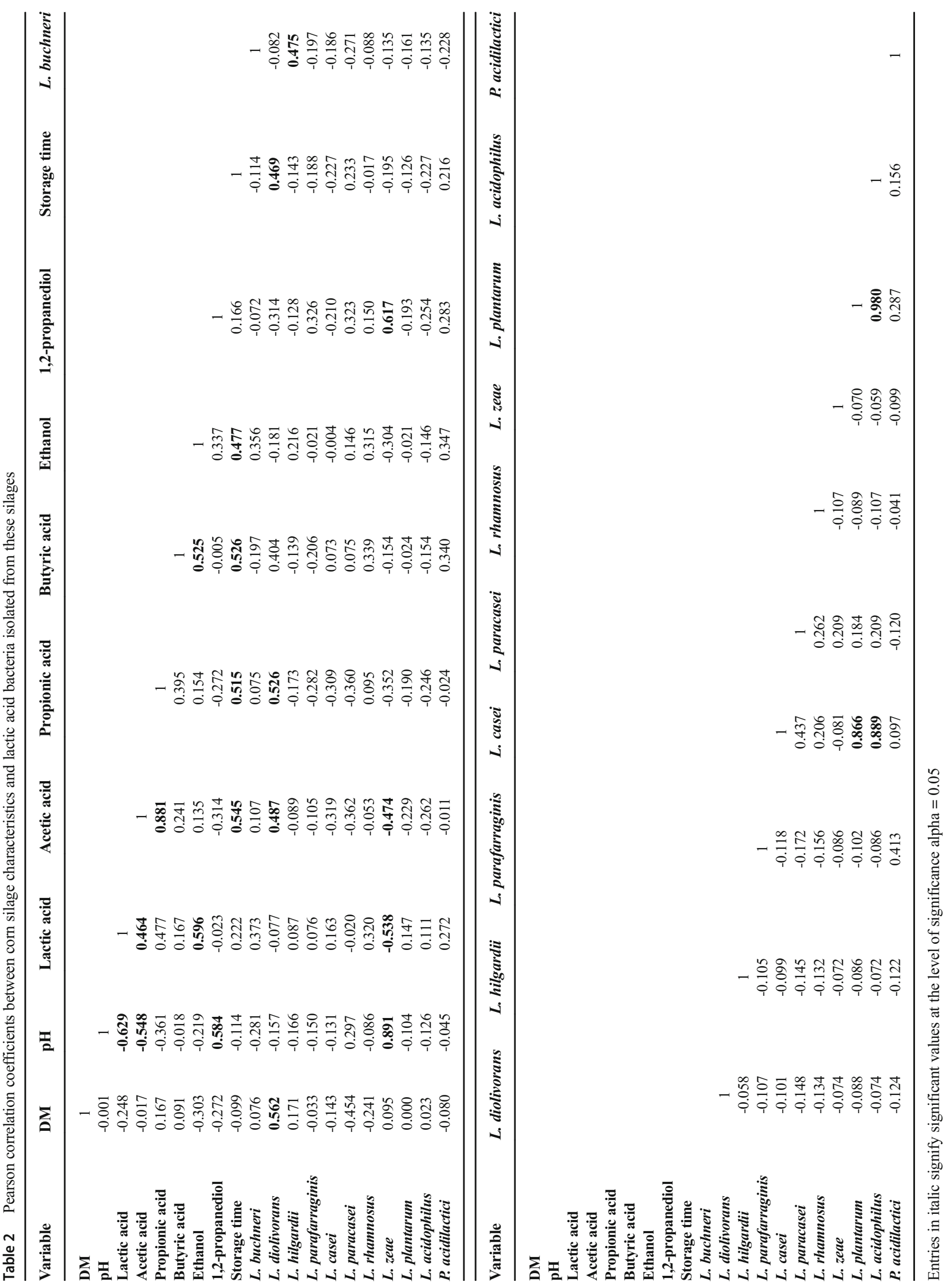


Table 3 Contents of lactic, acetic, and ethanol by CCMA and UFLA SLM LAB isolated from corn silage

\begin{tabular}{|c|c|c|c|c|c|c|}
\hline \multirow[t]{2}{*}{ Isolates } & \multirow[t]{2}{*}{ Identification ( $\%$ identity/code at NCBI) } & \multicolumn{4}{|c|}{ Metabolites (g/L) } & \multirow[t]{2}{*}{ Metabolism $^{1}$} \\
\hline & & Lactic & Acetic & Lactic/acetic ratio & Ethanol & \\
\hline UFLA SLM 223 & P. acidilactici & 20.55 & 0 & - & 0 & Homo \\
\hline UFLA SLM 111 & L. paracasei & 22.02 & 1.01 & 21.8 & 0.24 & Facult. hete. \\
\hline UFLA SLM 115 & L. paracasei & 21.94 & 1.02 & 21.5 & 0.18 & Facult. hete. \\
\hline UFLA SLM 118 & L. paracasei & 21.61 & 1.02 & 21.2 & 0.21 & Facult. hete. \\
\hline UFLA SLM 110 & L. rhamnosus & 22.66 & 1.08 & 21.0 & 0.24 & Facult. hete. \\
\hline CCMA 0790 & L. rhamnosus (100/KT982211.1) & 22.78 & 1.09 & 20.9 & 0.23 & Facult. hete. \\
\hline UFLA SLM 112 & L. paracasei & 21.63 & 1.05 & 20.6 & 0.19 & Facult. hete. \\
\hline CCMA 0782 & P. acidilactici (100/LC097074.1) & 20.96 & 1.02 & 20.5 & 0.3 & Homo. \\
\hline UFLA SLM 122 & L. paracasei & 21.11 & 1.04 & 20.3 & 0.21 & Facult. hete. \\
\hline UFLA SLM 121 & L. paracasei & 20.64 & 1.02 & 20.2 & 0.21 & Facult. hete. \\
\hline UFLA SLM 116 & L. paracasei & 20.61 & 1.03 & 20.0 & 0.18 & Facult. hete. \\
\hline CCMA 0789 & L. paracasei (100/KT159936.1) & 20.39 & 1.03 & 19.8 & 0.23 & Facult. hete. \\
\hline CCMA 0788 & L. paracasei $(100 / \mathrm{KT} 159936.1)$ & 20.47 & 1.04 & 19.7 & 0.18 & Facult. hete. \\
\hline CCMA 0787 & L. rhamnosus (100/KT982211.1) & 20.79 & 1.09 & 19.1 & 0.24 & Facult. hete. \\
\hline UFLA SLM 127 & P. acidilactici & 19.58 & 1.03 & 19.0 & 0.28 & Homo. \\
\hline UFLA SLM 128 & P. acidilactici & 19.35 & 1.06 & 18.3 & 0.27 & Homo. \\
\hline UFLA SLM 129 & L. plantarum & 18.29 & 1.04 & 17.6 & 0.28 & Facult. hete. \\
\hline CCMA 0784 & L. casei $(100 / \mathrm{JN} 560867.1)$ & 18.31 & 1.07 & 17.1 & 0.24 & Facult. hete. \\
\hline UFLA SLM 095 & L. paracasei & 21.63 & 1.46 & 14.8 & 0.23 & Facult. hete. \\
\hline UFLA SLM 017 & L. hilgardii & 17.47 & 1.19 & 14.7 & 0 & Obliga. hete. \\
\hline UFLA SLM 066 & L. hilgardii & 23.97 & 1.65 & 14.5 & 1.17 & Obliga. hete. \\
\hline CCMA 0781 & L. paracasei $(100 / \mathrm{KT} 159936.1)$ & 22.3 & 1.54 & 14.5 & 0.22 & Facult. hete. \\
\hline UFLA SLM 105 & L. casei & 14.38 & 1.03 & 14.0 & 0.25 & Facult. hete. \\
\hline UFLA SLM 101 & L. casei & 13.99 & 1.06 & 13.2 & 0.27 & Facult. hete. \\
\hline CCMA 0783 & L. casei $(100 / \mathrm{JN} 560867.1)$ & 14.23 & 1.08 & 13.2 & 0.26 & Facult. hete. \\
\hline UFLA SLM 043 & L. zeae & 22.97 & 1.76 & 13.1 & 0.21 & Facult. hete. \\
\hline UFLA SLM 039 & L. zeae & 23.29 & 1.8 & 12.9 & 0.2 & Facult. hete. \\
\hline CCMA 0774 & L. zeae $(100 / \mathrm{KT} 630827.1)$ & 23.22 & 1.81 & 12.8 & 0.21 & Facult. hete. \\
\hline UFLA SLM 040 & L. zeae & 23.3 & 1.82 & 12.8 & 0.21 & Facult. hete. \\
\hline UFLA SLM 089 & L. plantarum & 20.45 & 1.61 & 12.7 & 0.3 & Facult. hete. \\
\hline CCMA 0773 & L. paracasei (100/KT159936.1) & 22.7 & 1.79 & 12.7 & 0.22 & Facult. hete. \\
\hline UFLA SLM 042 & L. paracasei & 23.68 & 1.89 & 12.5 & 0.18 & Facult. hete. \\
\hline UFLA SLM 076 & L. buchneri & 22.29 & 1.79 & 12.5 & 0.29 & Obliga. hete. \\
\hline CCMA 0780 & L. plantarum (100/KP406154.1) & 21.1 & 1.7 & 12.4 & 0.31 & Facult. hete. \\
\hline UFLA SLM 087 & L. plantarum & 20.66 & 1.68 & 12.3 & 0.31 & Facult. hete. \\
\hline UFLA SLM 090 & L. plantarum & 21.36 & 1.77 & 12.1 & 0.33 & Facult. hete. \\
\hline CCMA 0766 & P. acidilactici (100/LC097074.1) & 20.09 & 1.68 & 12.0 & 0.31 & Homo. \\
\hline UFLA SLM 036 & L. rhamnosus & 21.68 & 1.84 & 11.8 & 0.54 & Facult. hete. \\
\hline UFLA SLM 001 & P. acidilactici & 20.58 & 1.75 & 11.8 & 0.31 & Homo. \\
\hline UFLA SLM 000 & P. acidilactici & 19.28 & 1.66 & 11.6 & 0.31 & Homo. \\
\hline UFLA SLM 086 & L. plantarum & 22.24 & 1.93 & 11.5 & 0.31 & Facult. hete. \\
\hline UFLA SLM 035 & L. rhamnosus & 16.15 & 1.57 & 10.3 & 0.18 & Facult. hete. \\
\hline UFLA SLM 102 & L. casei & 10.97 & 1.07 & 10.3 & 0.27 & Facult. hete. \\
\hline UFLA SLM 067 & L. hilgardii & 22.36 & 2.23 & 10.0 & 1.75 & Obliga. hete. \\
\hline CCMA 0770 & L. hilgardii (99/LC064898.1) & 25.33 & 2.55 & 9.9 & 2.01 & Obliga. hete. \\
\hline UFLA SLM 034 & L. rhamnosus & 15.61 & 1.61 & 9.7 & 0.18 & Facult. hete. \\
\hline CCMA 0786 & L. rhamnosus (100/KT982211.1) & 9.04 & 0.99 & 9.1 & 0.28 & Facult. hete. \\
\hline
\end{tabular}


Table 3 (continued)

\begin{tabular}{|c|c|c|c|c|c|c|}
\hline \multirow[t]{2}{*}{ Isolates } & \multirow[t]{2}{*}{ Identification ( $\%$ identity/code at NCBI) } & \multicolumn{4}{|c|}{ Metabolites (g/L) } & \multirow[t]{2}{*}{ Metabolism $^{1}$} \\
\hline & & Lactic & Acetic & Lactic/acetic ratio & Ethanol & \\
\hline UFLA SLM 107 & L. rhamnosus & 9.02 & 1.01 & 8.9 & 0.2 & Facult. hete. \\
\hline UFLA SLM 037 & L. rhamnosus & 13.64 & 1.56 & 8.7 & 0.17 & Facult. hete. \\
\hline CCMA 0785 & L. casei $(100 / \mathrm{JN} 560867.1)$ & 8.84 & 1.02 & 8.7 & 0 & Facult. hete. \\
\hline CCMA 0777 & L. buchneri (100/KR055508.1) & 12.67 & 1.52 & 8.3 & 3.56 & Obliga. hete. \\
\hline UFLA SLM 050 & L. buchneri & 9.52 & 1.18 & 8.1 & 0.2 & Obliga. hete. \\
\hline UFLA SLM 030 & L. buchneri & 11.95 & 1.51 & 7.9 & 3.49 & Obliga. hete. \\
\hline CCMA 0767 & L. rhamnosus (100/KT982211.1) & 16.49 & 2.12 & 7.8 & 0.28 & Facult. hete. \\
\hline UFLA SLM 072 & L. buchneri & 13.32 & 1.74 & 7.7 & 2.92 & Obliga. hete. \\
\hline CCMA 0779 & L. acidophilus (100/LN869545.1) & 10.74 & 1.48 & 7.3 & 0.38 & Homo. \\
\hline CCMA 0772 & L. buchneri (100/KR055508.1) & 12.73 & 1.76 & 7.2 & 2.42 & Obliga. hete. \\
\hline CCMA 0768 & L. buchneri (99/KR055508.1) & 12.54 & 1.74 & 7.2 & 3.85 & Obliga. hete. \\
\hline UFLA SLM 070 & L. buchneri & 14.63 & 2.05 & 7.1 & 3.7 & Obliga. hete. \\
\hline UFLA SLM 011 & L. buchneri & 13.72 & 2.02 & 6.8 & 4.21 & Obliga. hete. \\
\hline UFLA SLM 120 & L. buchneri & 13.39 & 2.02 & 6.6 & 4.31 & Obliga. hete. \\
\hline UFLA SLM 008 & L. buchneri & 14.96 & 2.27 & 6.6 & 4.64 & Obliga. hete. \\
\hline CCMA 0769 & L. buchneri (100/KR055508.1) & 14.27 & 2.19 & 6.5 & 4.62 & Obliga. hete. \\
\hline UFLA SLM 020 & L. hilgardii & 15.72 & 2.43 & 6.5 & 4.23 & Obliga. hete. \\
\hline UFLA SLM 021 & L. hilgardii & 16.66 & 2.59 & 6.4 & 4.31 & Obliga. hete. \\
\hline UFLA SLM 025 & L. hilgardii & 12.86 & 2.11 & 6.1 & 2.5 & Obliga. hete. \\
\hline UFLA SLM 019 & L. hilgardii & 13.4 & 2.3 & 5.8 & 3.38 & Obliga. hete. \\
\hline UFLA SLM 013 & L. hilgardii & 13.09 & 2.43 & 5.4 & 2.86 & Obliga. hete. \\
\hline CCMA 0775 & L. diolivorans (99/KP763951.1) & 14.88 & 2.8 & 5.3 & 2.99 & Obliga. hete. \\
\hline CCMA 0776 & L. diolivorans (99/KP763951.1) & 15.22 & 2.88 & 5.3 & 2.91 & Obliga. hete. \\
\hline UFLA SLM 061 & L. diolivorans & 16.11 & 3.07 & 5.2 & 3.66 & Obliga. hete. \\
\hline UFLA SLM 016 & L. hilgardii & 16.16 & 3.08 & 5.2 & 3.84 & Obliga. hete. \\
\hline UFLA SLM 018 & L. hilgardii & 12.06 & 2.3 & 5.2 & 2.87 & Obliga. hete. \\
\hline UFLA SLM 063 & L. diolivorans & 14.28 & 2.77 & 5.2 & 3.12 & Obliga. hete. \\
\hline UFLA SLM 062 & L. diolivorans & 15.72 & 3.11 & 5.1 & 3.26 & Obliga. hete. \\
\hline UFLA SLM 015 & L. hilgardii & 14.99 & 2.98 & 5.0 & 3.21 & Obliga. hete. \\
\hline UFLA SLM 073 & L. diolivorans & 14.01 & 2.79 & 5.0 & 3.27 & Obliga. hete. \\
\hline UFLA SLM 057 & L. diolivorans & 12.93 & 2.59 & 5.0 & 3.12 & Obliga. hete. \\
\hline CCMA 0771 & L. hilgardii (99/LC064898.1) & 12.99 & 2.65 & 4.9 & 2.97 & Obliga. hete. \\
\hline UFLA SLM 059 & L. diolivorans & 12.82 & 2.63 & 4.9 & 2.98 & Obliga. hete. \\
\hline UFLA SLM 014 & L. hilgardii & 16.79 & 3.47 & 4.8 & 3.33 & Obliga. hete. \\
\hline UFLA SLM 026 & L. hilgardii & 15.58 & 3.32 & 4.7 & 3.94 & Obliga. hete. \\
\hline CCMA 0778 & L. hilgardii (99/LC064898.1) & 11.2 & 2.4 & 4.7 & 1.69 & Obliga. hete. \\
\hline CCMA 0765 & L. parafarraginis (99/KR055510.1) & 11.42 & 2.48 & 4.6 & 2.95 & Facult. hete. \\
\hline UFLA SLM 022 & L. hilgardii & 11.48 & 2.64 & 4.3 & 1.67 & Obliga. hete. \\
\hline UFLA SLM 004 & L. parafarraginis & 14.57 & 3.42 & 4.3 & 3.98 & Facult. hete. \\
\hline UFLA SLM 058 & L. diolivorans & 12.73 & 3.02 & 4.2 & 3.07 & Obliga. hete. \\
\hline UFLA SLM 075 & L. diolivorans & 16.82 & 4.11 & 4.1 & 3.73 & Obliga. hete. \\
\hline
\end{tabular}

${ }^{1}$ Type of glucose fermentation, obligately homofermentative, facultatively heterofermentative, and obligately heterofermentative

influence of ensiling temperature $\left(5\right.$ to $25^{\circ} \mathrm{C}$ ) on fermentation characteristics and microbial counts of corn silage and the results clearly demonstrated that changes in the LAB population diversity occurred during the ensiling process. An expressive increase in LAB counts was detected after 28 days of ensiling at $25{ }^{\circ} \mathrm{C}$. Furthermore, in these silages, the 
Fig. 3 Principal component analysis of the lactic acid, acetic acid and ethanol of UFLA SLM and CCMA isolates evaluated

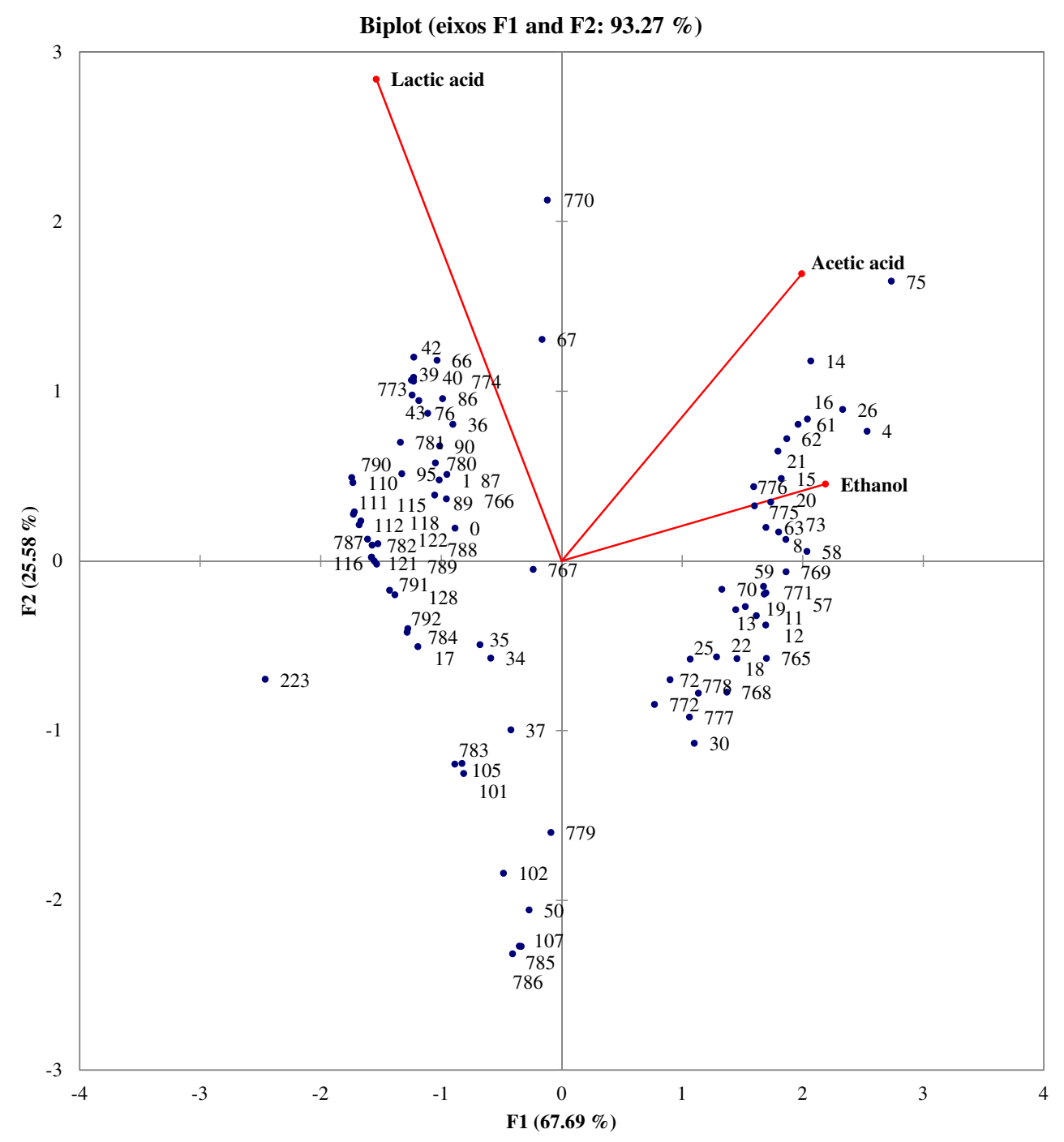

growth of $L$. plantarum and $P$. pentosaceus was gradually replaced by L. buchneri, whereas the homolactic bacterium L. sakei and L. curvatus dominated the fermentation at 5 and $10{ }^{\circ} \mathrm{C}$, supporting the broad consensus concerning the shift from homo- to heterofermentative LAB species during ensiling. The correlation between L. buchneri and L. hilgardii (both obligately heterofermentative) presence in silages was observed. However, there was no correlation of the presence of these species with long silage storage time.

The isolation of L. acidophilus in silages is not common and was isolated only in the Itumirin region. In this region were observed great LAB species diversity, and great population of filamentous fungi and yeasts. Lactobacillus acidophilus with feruloyl esterase activity (FAE) was isolated from corn silage produced in laboratory silos in Japan. LAB that show activity with this enzyme can improve silage quality and digestibility (Xu et al., 2017a). Strains of this species may have probiotic characteristics (Bomba et al., 2012). In review, Queiroz et al. (2018) report L. acidophilus reduced the pathogenic Escherichia coli presence in the intestine when orally administered to ruminants. The presence of L. acidophilus was positively correlated with $L$. plantarum and $L$. casei in silages, although these microorganisms has been used as starter cultures in several fermentative processes, we have not found any reports in the literature about the possible explanation for this association.

Lactobacillus buchneri is one of the obligately heterofermentative LAB often studied as a silage inoculant in recent years (Blajman et al., 2018). This species was frequently isolated in corn silages produced in southern Minas Gerais, Brazil. Rossi and Dellaglio (2007) and Ávila et al. (2009) also found a high L. buchneri population in alfalfa, corn (Italy) and sugarcane (Brazil) silages. Because this species is obligately heterofermentative and some strains present a high production of acetic acid, the main result of its inoculation in silages is the reduction of the yeast and mould population and improvement in aerobic stability (Blajman et al. 2018). Lactobacillus buchneri can produce acetic acid by hexoses fermentation or by the anaerobic degradation of lactic acid. During the anaerobic degradation of lactic acid, 1,2- 
propanediol is also produced. Lactobacillus diolivorans, a LAB isolated from corn silage (Krooneman et al., 2002), is associated with the degradation of 1,2-propanediol to propionic acid and 1-propanol. The correlation of the L. diolivorans presence with silages with high propionic acid concentration may be justified by this metabolism. The products of $L$. diolivorans metabolism are important for improving silage aerobic stability. There are few studies that describe the presence of this species in silages and few studies on the inoculation of $L$. diolivorans in silages; therefore, how this bacterium acts during the silage fermentation is still unknown.

The species L. hilgardii was isolated in the silages sampled in the regions of Elói Mendes and Piranguinho, and in this last region only obligately heterofermentative species were identified. Lactobacillus hilgardii was isolated during the fermentation of sugarcane silage in experimental silos (Ávila et al. 2014). The inoculation of the CCMA 0170 (L. hilgardii) strain in sugarcane and corn silages resulted in lower dry matter loss, lower yeast and filamentous fungi population and higher acetic acid concentration and aerobic stability (Assis et al. 2014; Carvalho et al. 2015; Reis et al. 2017). The inoculation of the CNCM I-4705 (L. hilgardii) strain on corn silage produced in Italy obtained similar results (Ferrero et al. 2019). The L. parafarraginis species, also belonging to the L. buchneri group, was isolated only in the Lavras region. The silage characteristics (DM, $\mathrm{pH}$, acid concentrations, microorganism's population) of this region can be classified as of good quality and in these silages was not detected filamentous fungi growth. This species has recently been studied as a silage inoculant as reviewed by Muck et al. (2018). Inoculation with $L$. parafarraginis has resulted in silages with higher aerobic stability when compared with control silage or silage inoculated with L. buchneri when fermentation occurred at low temperatures (Liu et al. 2014). The diversity of LAB inoculated with L. brevis (SDMCC050297) and L. parafarraginis (SDMCC050300) in corn stover silages in China was lower when compared with the non-inoculated silages. Lactobacillus plantarum and Lactococcus lactis were dominant in control silages, and L. brevis and L. parafarraginis were dominant in the silages inoculated with these species after 10 days of storage (Xu et al. 2017b). These authors observed the amount of LAB and the abundance of Lactobacillales in inoculated silages were higher than in the control.

Lactobacillus plantarum was isolated in only two regions, although the presence of this species in silages is common everywhere (Parvin and Nishino 2009; Ávila et al. 2014; Carvalho et al. 2016; Hu et al. 2018). The use of L. plantarum as an inoculant is well known and new strains are constantly evaluated, making this species one of the most studied as an inoculant for silage (Blajman et al. 2018; Hu et al. 2018). The primary results of $L$. plantarum inoculation in silages are a fast drop in $\mathrm{pH}$ and lower DM losses.
However, inoculation results in decreased aerobic stability, and therefore. this species is widely used in combination with other LAB species, mainly obligately heterofermentative species.

The facultative heterofermentative $L$. casei species has been studied and used as a silage inoculant (Muck et al. 2018). The occurrence of this species in the silages evaluated was low (found in only one region). The silages of this region had on average the highest filamentous fungi and yeast counts and LAB diversity. In these silages were also observed lowest average of propionic acid content $(6.6 \mathrm{~g} / \mathrm{kg} \mathrm{DM})$ that has antifungal effect. The safety and efficacy of the $L$. casei (DSM 28872) strain used as an additive intended to improve ensiling was analysed, and the results showed this strain has the potential to improve silage production by reducing dry matter loss and enhancing protein preservation (Rychen et al. 2017). Other species belonging to the $L$. casei group that were isolated are L. paracasei, L. rhamnosus, and L. zeae. The use of L. paracasei (Avila et al. 2010) and L. rhamnosus ( $\mathrm{Li}$ and Nishino 2011) as additives for silage was reported; however, when this species was compared with other LAB, the results of the inoculation were not satisfactory. Lactobacillus zeae was found only in the Passos region, the silages from this region presented high $\mathrm{pH}$ values and low lactic and acetic acid concentrations. This species was also isolated from the alfalfa silage (which also have high $\mathrm{pH}$ values) produced in farm scale silos in Italy (Rossi and Dellaglio 2007). Little is known about the performance of this species during silage fermentation, and no studies evaluating $L$. zeae as an inoculant were found.

Pediococcus acidilactici was identified in three evaluated regions. This species is among the most common homofermentative LAB used as silage inoculants, although there are few studies evaluating its performance and it is frequently inoculated together with other LAB (Blajman et al. 2018). Pediococcus acidilactici dominate the early stages of ensilage and rapidly decrease $\mathrm{pH}$ (Fitzsimons et al., 1992). Although no significant correlation was observed with storage time, this species was isolated from silages with an average storage time of 380 days.

The ability to clearly differentiate between the LAB isolates was low for the isolates identified using the (GACA) $)_{4}$ primer. A reduced number of bands were observed, making it difficult to distinguish single groups according to species. In contrast, the M13 fingerprint profiles were relatively heterogeneous. This variability can be useful for intraspecific differentiation of isolates within the same species (Turková et al. 2012). The M13 primer has already been used for Lactobacilli typing and has proven useful for the differentiation of a wide range of Lactobacilli at the species and subspecies levels, and potentially, up to the strain level (Rossetti and Giraffa, 2005; Švec et al. 2010). In evaluating the genotypic profile obtained by M13, small differences in the band profile between isolates 
within the same species were observed. However, some strains isolated from different silages showed the same band profile, thus suggesting the presence of clusters with high similar fingerprints in silages from various regions. The identification at a species level substantiates suitability of bacterial strains for industrial application. For example, their performance as starter cultures, which is strain dependent. The results demonstrate the usefulness of M13 fingerprinting as a rapid method and alternative strategy for subspecies identification; this technique enabled the precise grouping of isolated LAB isolates.

Knowledge about LAB metabolism is important to predict its effect as a starter on silage. Lactic acid plays an important role in the rapid reduction of $\mathrm{pH}$, causing the inhibition of undesirable microorganisms that grow in the anaerobic fermentation stage, but it does not act by inhibiting the microorganisms' aerobic deterioration. In addition to contributing to $\mathrm{pH}$ reduction, acetic acid and propionic acid have an antifungal effect and inhibit spoilage during the aerobic stage of silage fermentation.

The results of this study show that, in general, bacterial species with a heterofermentative metabolism produce higher concentrations of acetic acid, which is important for inhibiting aerobic spoilage. This property is desirable in silage with a spoilage problem, such as a corn silage. However, it is important to note that there may be differences between strains of the same species. Thus, the selection of strains for inoculants should be based at the strain level and not only the species.

\section{Conclusion}

This research has contributed to our understanding of the bacterial community structure of LAB present in farm scale corn silage produced in a warm climate, such as the Brazilian state of Minas Gerais. Eleven different LAB species were identified and characterised. All the LAB species found were previously associated with silages from corn or other plants produced at different locations. The species $L$. buchneri, $L$. diolivorans, $L$. hilgardii, L. paracasei and $L$. rhamnosus were found in greater proportion in the silages evaluated. Differences in organic acid production were observed among the strains belonging to the same species. Further studies can assess the potential of these isolates as starter cultures to produce corn silage and other forage crops.

Funding information The study was financially supported by the Brazilian agencies CNPq (Conselho Nacional de Desenvolvimento Científico e Tecnológico), FAPEMIG (Fundação de Amparo a Pesquisa do Estado de Minas Gerais) and CAPES (Coordenação de Aperfeiçoamento de Pessoal de Nível Superior). At the University of Minho the study was supported by the Portuguese Foundation for Science and Technology (FCT) under the scope of the strategic funding of the UID/BIO/04469/2013 unit and COMPETE 2020 (POCI-01-0145-
FEDER-006684), and the BioTecNorte operation (NORTE-01-0145FEDER-000004) funded by the European Regional Development Fund under the scope of Norte 2020-Programa Operacional Regional do Norte.

\section{Compliance with ethical standards}

Conflicts of interest The authors declare that they have no conflict of interest.

Research involving human participants and/or animals Not applicable

Informed consent Not applicable

Open Access This article is distributed under the terms of the Creative Commons Attribution 4.0 International License (http:// creativecommons.org/licenses/by/4.0/), which permits unrestricted use, distribution, and reproduction in any medium, provided you give appropriate credit to the original author(s) and the source, provide a link to the Creative Commons license, and indicate if changes were made.

\section{References}

Abdollahniya D, Hosseini SM, Baghbaderani BK, Mordadi A, Arabestani MR (2018) Identification of Lactobacillus species isolated from traditional dairy products using RAPD-PCR. Avicenna J Clin Microbiol Infect 5:7-13. https://doi.org/10.15171/ajcmi.2018. 02

Assis FGV, Avila CLS, Pinto JC, Schwan RF (2014) New inoculants on maize silage fermentation. R Bras Zootec 43:395 -39403. https:// doi.org/10.1590/S1516-35982014000800001

Avila CLS, Valeriano AR, Pinto JC, Figueiredo HCP, Rezende AV, Schwan RF (2010) Chemical and microbiological characteristics of sugar cane silages treated with microbial inoculants. R Bras Zootec 39:25-32. https://doi.org/10.1590/S151635982010000100004

Bernardes TF, do Rêgo AC (2014) Study on the practices of silage production and utilization on Brazilian dairy farms. J Dairy Sci 97 : 1852-1861. https://doi.org/10.3168/jds.2013-7181

Bernardes TF, Daniel JLP, Adesogan AT, McAllister TA, Drouin P, Nussio LG, Cai Y (2018) Silage review: unique challenges of silages made in hot and cold regions. J Dairy Sci 101(5):4001-4019. https://doi.org/10.3168/jds.2017-13703

Blajman JE, Páez RB, Vinderola CG, Lingua MS, Signorini ML (2018) A meta-analysis on the effectiveness of homofermentative and heterofermentative lactic acid bacteria for corn silage. J Appl Microbiol 125:1655-1669. https://doi.org/10.1111/jam.14084

Bomba A, Nemcová R, Strojný L, Mudroňová D (2012) Probiotics for Farm Animals. In: Lahtinen S, Ouwehand AC, Salminen S, Von Wright A (eds) Lactic acid bacteria - microbiological and functional aspects, 4th edn. Taylor \& Francis, Florida, pp 633-670

Borreani G, Tabacco E, Schmidt RJ, Holmes BJ, Muck RE (2018) Silage review: factors affecting dry matter and quality losses in silages. J Dairy Sci 101:3952-3979. https://doi.org/10.3168/jds.2017-13837

Carvalho BF, Avila CL, Miguel MGCP, Pinto JC, Santos MC, Schwan RF (2015) Aerobic stability of sugarcane silage inoculated with tropical strains of lactic acid bacteria. Grass Forage Sci 70:308323. https://doi.org/10.1111/gfs.12117

Carvalho BF, Avila CLS, Bernardes TF, Pereira MN, Santos C, Schwan RF (2016) Fermentation profile and identification of lactic acid 
bacteria and yeasts of rehydrates corn kernel silage. J Appl Microbiol 122:589-600. https://doi.org/10.1111/jam.13371

Doi K, Nishizaki Y, Kimura H, Kitahara M, Fujino Y, Ohmomo S, Ohshima T, Ogata S (2013) Identification of thermo tolerant lactic acid bacteria isolated from silage prepared in the hot and humid climate of Southwestern Japan. SpringerPlus 2(1):485. https://doi. org/10.1186/2193-1801-2-485

Dolci P, Cocolin L (2017) Direct application of Rep-PCR on type I sourdough matrix to monitor the dominance and persistence of a Lactobacillus plantarum starter throughout back-slopping. J Food Sci 82:1898-1901. https://doi.org/10.1111/1750-3841.13804

Fabiszewska AU, Zielińska KJ, Wróbel B (2019) Trends in designing microbial silage quality by biotechnological methods using lactic acid bacteria inoculants: a minireview. World J Microbiol Biotechnol 35(5). https://doi.org/10.1007/s11274-019-2649-2

Ferrero F, Piano S, Tabacco E, Borreani G (2019) Effects of conservation period and Lactobacillus hilgardii inoculum on the fermentation profile and aerobic stability of whole corn and sorghum silages. J Sci Food Agric 99:2530-2540. https://doi.org/10.1002/jsfa.9463

Fitzsimons A, Duffner F, Curtin D, Brophy G, O'Kiely P, O'Connell M (1992) Assessment of Pediococcus acidilactici as a potential silage inoculant. Appl Environ Microbiol 58:3047-3052

Gevers D, Huys G, Swings J (2001) Applicability of rep-PCR fingerprinting for identification of Lactobacillus species. FEMS Microbiol Lett 205:31-36. https://doi.org/10.1111/j.1574-6968.2001.tb10921.x

Guan H, Yan YH, Li XL, Li XM, Shuai Y, Feng GY, Ran QF, Cai YM, Li Y, Zhang XQ (2018) Microbial communities and natural fermentation of corn silage prepared with farm bunker-silo in Southwest China. Bioresour Technol 265:282-290. https://doi.org/10.1016/j. biortech.2018.06.018

Hu Z, Chang J, Yu J, Li S, Niu H (2018) Diversity of bacterial community during ensiling and subsequent exposure to air in whole-plant maize silage. Asian-Australas J Anim Sci 31:1464-1473. https://doi.org/ 10.5713/ajas. 17.0860

Khaing KT, Loh TC, Ghizan S, Halim RA, Samsudin AA (2015) Feed intake, growth performance and digestibility in goats fed whole corn plant silage and Napier grass. Mal J Anim Sci 18:87-98

Khan NA, Yu P, Ali M, Cone JW, Hendriks WH (2015) Nutritive value of maize silage in relation to dairy cow performance and milk quality. J Sci Food Agric 95:238-252. https://doi.org/10.1002/jsfa.6703

Krooneman J, Faber F, Alderkamp AC, Elferink OSJHW, Driehuis F, Cleenwerck I, Swings J, Gottschal JC, Vancanneyt M (2002) Lactobacillus diolivorans sp nov, a 1,2-propanediol-degrading bacterium isolated from aerobically stable maize silage. Int J Syst Evol Microbiol 52:639-646. https://doi.org/10.1099/00207713-52-2-639

Lane D (1991) 16S/23S rRNA sequencing nucleic acid techniques. In: Stackebrandt E, Goodfellow M (eds) Bacterial Systematics. Wiley, Chichester, pp 115-175

Li Y, Nishino N (2011) Effects of inoculation of Lactobacillus rhamnosus and Lactobacillus buchneri on fermentation, aerobic stability and microbial communities in whole crop corn silage. J Jpn Grassl Sci 57:184-191. https://doi.org/10.1111/j.1744-697X.2011.00226.x

Lin C, Bolsen KK, Brent BE, Fung DYC (1992) Epiphytic lactic acid bacteria succession during the pre-ensiling and ensiling periods of alfalfa and maize. J Appl Microbiol 73:375-387. https://doi.org/10. 1111/j.1365-2672.1992.tb04992.x

Liu QH, Yang FY, Zhang JG, Shao T (2014) Characteristics of Lactobacillus parafarraginis $\mathrm{ZH} 1$ and its role in improving the aerobic stability of silages. J Appl Microbiol 117:405-416. https://doi. org/10.1111/jam. 12530

Makau DN, VanLeeuwen JA, Gitau GK, Muraya J, McKenna SL, Walton C, Wichtel JJ (2018) Animal and management factors associated with weight gain in dairy calves and heifers on smallholder dairy farms in Kenya. Prev Vet Med 161:60-68. https://doi.org/10.1016/j. prevetmed.2018.10.017
McDonald P, Henderson AR, Whittenbury R (1966) The effect of temperature on ensilage. J Sci Food Agric 17:476-480. https://doi.org/ 10.1002/jsfa.2740171009

McDonald P, Henderson AR, Heron SJE (1991) Biochemistry of silage, 2nd edn. 781 Marlow: Chalcombe, UK

Muck R (2013) Recent advances in silage microbiology. Agric. Food Sci 22:3-15. https://doi.org/10.23986/afsci.6718

Muck RE, Nadeau EMG, Mc Allister TA, Contreras-Govea FE, Santos MC, Kung L Jr (2018) Silage review: recent advances and future uses of silage additives. J Dairy Sci 101:3980-4000. https://doi.org/ 10.3168/jds.2017-13839

Ohmomo S, Nitisinprasart S, Hiranpradit S (2002) Silage-making and recent trend of dairy farming in Thailand. JARQ 36:227-234. https://doi.org/10.6090/jarq.36.227

Parente E, Guidone A, Matera A, De Filippis F, Mauriello G, Ricciardi A (2016) Microbial community dynamics in thermophilic undefined milk starter cultures. Int J Food Microbiol 217:59-67. https://doi. org/10.1016/j.ijfoodmicro.2015.10.014

Parvin P, Nishino N (2009) Succession of lactic acid bacteria in wilted rhodesgrass silage assessed by plate culture and denaturing gradient gel electrophoresis. Grassl Sci 56:51-55. https://doi.org/10.1111/j. 1744-697X.2009.00173.x

Prospero-Bernal F, Martínez-Garcia CG, Olea-Pérez R, López-González F, Arriaga-Jordán CM (2017) Intensive grazing and maize silage to enhance the sustainability of small-scale dairy systems in the highlands of Mexico. Trop Anim Health Prod 49:1537-1544. https://doi. org/10.1007/s11250-017-1360-2

Queiroz OCM, Ogunade IM, Weinberg Z, Adesogan AT (2018) Silage review: foodborne pathogens in silage and their mitigation by silage additives. J Dairy Sci 101:4132-4142. https://doi.org/10.3168/jds. 2017-13901

Reis CB, Santos AO, Carvalho BF, Schwan RF, Avila CLS (2017) Wild Lactobacillus hilgardii (CCMA 0170) strain modifies the fermentation profile and aerobic stability of corn silage. J Appl Anim Res 46: 632-638. https://doi.org/10.1080/09712119.2017.1371609

Rossetti L, Giraffa G (2005) Rapid identification of dairy lactic acid bacteria by M13-generated, RAPD-PCR fingerprint databases. J Microbiol Methods 63:135-144. https://doi.org/10.1016/j.mimet. 2005.03.001

Rossi F, Dellaglio F (2007) Quality of silages from Italian farms as attested by number and identity of microbial indicators. J Appl Microbiol 103:1707-1715. https://doi.org/10.1111/j.1365-2672. 2007.03416.x

Rychen G, Aquilina G, Azimonti G et al (2017) Scientific opinion on the safety and efficacy of Lactobacillus casei DSM 28872 as a silage additive for all animal species. EFSA J 15:4703. https://doi.org/10. 2903/j.efsa.2017.4703

Sachinandan D, Gurpreet K, Amit R, Gaurav D, Ramakant K, Paras Y, Rameshwar S, Tirtha KD, Surender LG (2010) A simple method for the efficient isolation of genomic DNA from Lactobacilli isolated from traditional Indian fermented milk (Dahi). Indian J Microbiol 50:412-418. https://doi.org/10.1007/s12088-011-0079-4

Santos AO (2016) Caracterização de silagens de milho produzidas em minas gerais e caracterização metabólica e genotípica de bactérias do ácido lático isoladas dessas silagens. Federal University of Lavras, Doctoral thesis

Santos AO, Dias Junior GS, Pereira MN, Schwan RF, Ávila CLS (2020) A survey of whole-plant corn silages from Minas Gerais dairy farms. Sci Agrár 77(2):1-10. https://doi.org/10.1590/1678-992X-20180080

Shehata AS, Mukherjee PK, Aboulatta HN, El Akhras AI, Abbadi SH, Ghannoum MA (2008) Single-step PCR using (GACA) 4 primer: utility for rapid identification of dermatophyte species and strains. J Clin Microbiol 46:2641-2645. https://doi.org/10.1128/JCM. 00697-08 
Švec P, Kukletova M, Sedlaček I (2010) Comparative evaluation of automated ribotyping and RAPD-PCR for typing of Lactobacillus spp occurring in dental carries. Antonie Van Leeuwenhoek 98:85-92. https://doi.org/10.1007/s10482-010-9432-6

Tamir B, Gebrehawariat E, Tegegne A, Kortu MY (2012) Rumen degradability characteristics of normal maize stover and silage, and quality protein maize silage-based diets offered to cows. Trop Anim Health Prod 44:1547-1553. https://doi.org/10.1007/s11250-012-0104-6

Torriani S, Zapparoli G, Dellaglio F (1999) Use of PCR-based methods for rapid differentiation of Lactobacillus delbrueckii subsp bulgaricus and L delbrueckii subsp lactis. Appl Environ Microbiol 65:4351-4356

Turková K, Rittich B, Španová A (2012) Identification and determination of relatedness of lactobacilli using different DNA amplification methods. Chem Pap 66:842-851. https://doi.org/10.2478/s11696012-0206-7

Vandamme P, Bruyne K, Pot B (2014) Phylogenetics and systematics. In: Holzapfel WH, Wood BJB (eds) Lactic acid bacteria - biodiversity and taxonomy. Wiley, Chichester, pp 31-45

Xu Z, He H, Zhang S, Guo T, Kong J (2017a) Characterization of feruloyl esterases produced by the four lactobacillus species: L. amylovorus, L. acidophilus, L. farciminis and L. fermentum, isolated from ensiled corn stover. Front Microbiol 8:941. https://doi.org/10.3389/fmicb. 2017.00941

Xu Z, He H, Zhang S, Kong J (2017b) Effects of inoculants Lactobacillus brevis and Lactobacillus parafarraginis on the fermentation characteristics and microbial communities of corn stover silage. Sci Rep 7: 13614. https://doi.org/10.1038/s41598-017-14052-1

Yang HY, Wang XF, Liu JB, Gao LJ, Ishii M, Igarashi Y, Cui ZJ (2006) Effects of water-soluble carbohydrate content on silage fermentation of wheat straw. J Biosci Bioeng 101:232-237. https://doi.org/10. $1263 / \mathrm{jbb} .101 .232$

Yang Y, Ferreira G, Corl BA, Campbell BT (2019) Production performance, nutrient digestibility, and milk fatty acid profile of lactating dairy cows fed corn silage- or sorghum silage-based diets with and without xylanase supplementation. J Dairy Sci 102:1-9. https://doi. org/10.3168/jds.2018-15801

Zhou Y, Drouin P, Lafrenière C (2016) Effect of temperature $\left(5-25^{\circ} \mathrm{C}\right)$ on epiphytic lactic acid bacteria populations and fermentation of wholeplant corn silage. J Appl Microbiol 121(3):657-671. https://doi.org/ 10.1111/jam. 13198

Publisher's note Springer Nature remains neutral with regard to jurisdictional claims in published maps and institutional affiliations. 